\title{
Yield Improvement in Wave Soldering Process by Using Customised Pallets
}

\author{
Dr.Salil Dey ${ }^{1}$, Mr. Prince Kumar ${ }^{2}$ \\ ${ }^{1}$ Additional General Manager, Bharat Electronics Limited,Panchkula (Haryana), India \\ ${ }^{2}$ Deputy Manager, Bharat Electronics Limited, Panchkula(Haryana), India
}

\begin{abstract}
Presently there are two types of components available in the Electronic Industries;they are 1. Surface-mounted Devices 2. Leaded components (through-hole components). Surface-mounted components can be assembled at first speed due to automation in the mounting and reflow soldering process. But the speed at which leaded components are mounted and soldered is not that fast. Hence there is always a challenge to match the production rate of PCB having leaded and surface mounted devices.
\end{abstract}

Keywords:SMD, PCB, ESD

1. Introduction:

The manufacturing of PCB assembly has undergone tremendous change. The change in process is necessitated due to an increase in demand for Electronics goods. To meet the demand, the component industry also changed the size and shape of components. Presently components are small in size and most of the components are changed to surface-mounted devices (SMD) for the ease of manufacturing. In the early 1970 most of the components used in the electronics industry were leaded components but today all almost all components are surfacemounted devices and very few are leaded components. Due to the change in the shape of the component, the assembly process has also undergone a change.

In earlier days since most of the components were leaded hence wave soldering techniques were mostly used apart from hand soldering. In the present context, reflow soldering is used to assemble surface-mounted components. In addition to surface-mounted devices, other leaded components are assembled by hand soldering or by selective soldering, or robotic soldering. In this case,the use of wavesoldering is very much limited. Wave soldering is a very fast and reliable process. Hence it is a challengeto use the wave soldering process in the presence of mixedcomponents technology.

2. Research Problem:

In the manufacturing industry, quite a good number of PCBs to be assembled within a short period of time. Total components consist of both surface-mounted devices and leaded components like connectors, relay, etc.

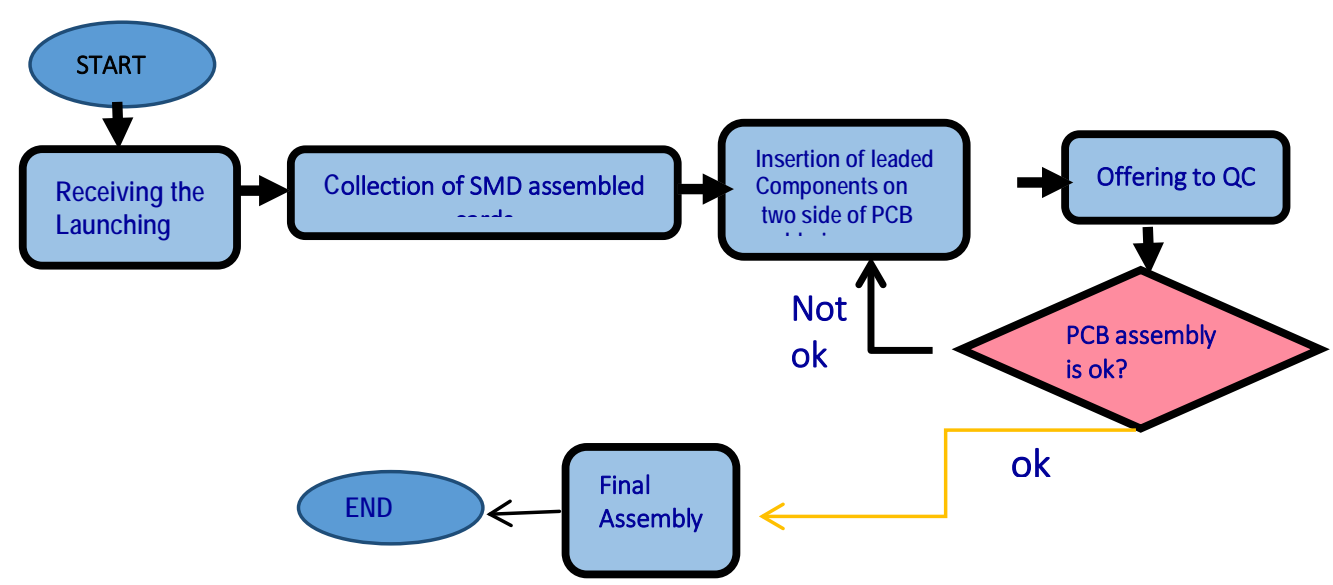

Fig 1: Leaded Assembly process map 
Out of total components, about 95\% components are surface mounted devices and balance was leaded components. As per manufacturing processes all surface mounted devices are to be soldered by the reflow soldering process. The process map is shown in Fig 1.

Assembly for rest of the leaded components the options were

1. Robotic soldering of leaded components.

2. Selective soldering

3. Wave soldering.

4. Hand soldering.

The volume of production per day is very huge. Both Robotic soldering and selective soldering facility were not available and due to the quickdelivery period for completion of the project, it was not possible to buy the machines. Another alternative option was to use wave soldering which was very difficult since both sides of the PCBs were having surface-mounted components [1]. The last option was to go for the hand soldering process. Since the volume of production was very high, whether it would be economically viable to employ those many people to get the required output [2], [3]. Moreover, hand soldering quality depends upon person to person, thus soldering quality can vary. Currently,the assembly process of leaded component calls for hand soldering. The limitations of the hand soldering process are as follows:

Individual operators need to mount all the leaded components which isa complex and time-consuming process.

1. The operator needs to use tools \& consumables like Flux, soldering iron, solder wire for soldering of components which is a tedious process.

2. Quality of Soldering process mainly depends on skills of operators which can bring lack of uniformity in soldering joint.

3. There are always chances of getting dry soldered/excess solder and other soldering defects due to the manual soldering process as the operator may forget due to required target pressure.

4. Arranging Consumables Like Flux, Soldering Iron, Soldering Wire,etc. are time-consuming for supervisors.

The challenge is to get the optimum solution for the assembly process of leaded components.

3. Methodology:

Hand soldering process along with manual insertion process for assembly of leaded components is shown in Table1. 
Table 1: Operation time process

\begin{tabular}{|c|c|c|}
\hline Sr. No. & Process step & $\begin{array}{c}\text { Operation time } \\
\text { in minutes }\end{array}$ \\
\hline 1. & Insertion of Leaded Components on the First side & 5 \\
\hline 2. & Soldering of Leaded Component on First Side & 6 \\
\hline 3 & Insertion of Leaded Components on the Second \\
side & 6 \\
\hline 4 & Soldering of Leaded Component on second Side & 7 \\
\hline 5 & Packing in ESD Bags & 0.5 \\
\hline & Total Time & 24.5 \\
\hline
\end{tabular}

The present status at which the manufacturing is to be carried is shown in Table 2 .

Table 2: Critical to Process

\begin{tabular}{|c|c|c|c|c|c|}
\hline Sr. No. & Business Need & $\begin{array}{c}\text { Critical to } \\
\text { Process }\end{array}$ & $\begin{array}{c}\text { Defect } \\
\text { Definition }\end{array}$ & Status & $\begin{array}{l}\text { Kano } \\
\text { Status }\end{array}$ \\
\hline 1. & $\begin{array}{c}\text { Efficient } \\
\text { Leadedassembl } \\
\text { y process of } \\
\text { PCB }\end{array}$ & $\begin{array}{l}\text { All operational } \\
\text { parameters as per } \\
\text { Documents. } \\
\text { Reduction in } \\
\text { manual work } \\
\text { content } \\
\text { Reduction in } \\
\text { manufacturing } \\
\text { time }\end{array}$ & $\begin{array}{c}\text { The process } \\
\text { not as per } \\
\text { standard } \\
\text { Higher } \\
\text { manualwork } \\
\text { content } \\
\text { Higher the } \\
\text { Leaded } \\
\text { assembly time }\end{array}$ & $\begin{array}{l}\text { Cycle time } \\
\text { of Leaded } \\
\text { assembly of } \\
\text { equipment } \\
>0.1 \mathrm{Hr}\end{array}$ & $\begin{array}{c}\text { Must } \\
\text { Be }\end{array}$ \\
\hline
\end{tabular}

Critical analysis of the requirements done and is shown in Table 3.

Table 3: Critical Analysis of requirement

\begin{tabular}{|c|c|c|c|c|c|}
\hline Sr. No. & $\begin{array}{c}\text { Activity } \\
\text { Description }\end{array}$ & $\begin{array}{c}\text { Skills } \\
\text { Required }\end{array}$ & $\begin{array}{c}\text { Improvement } \\
\text { Required }\end{array}$ & Impact & Alternative \\
\hline 1. & $\begin{array}{c}\text { Kit } \\
\text { Collection }\end{array}$ & Medium & No & Nil & Nil \\
\hline 2. & $\begin{array}{c}\text { Insertion of } \\
\text { Components } \\
\text { Manually on } \\
\text { Top Side }\end{array}$ & Medium & No & Nil & $\begin{array}{c}\text { With the } \\
\text { help of top } \\
\text { side Jig, } \\
\text { component } \\
\text { can be held } \\
\text { \& Manual } \\
\text { soldering to } \\
\text { be replaced } \\
\text { by wave }\end{array}$ \\
\hline 3. & $\begin{array}{c}\text { Soldering of } \\
\text { Components }\end{array}$ & High & Yes & $\begin{array}{c}\text { Consumption } \\
\text { of } \\
\text { Consumables } \\
\text { \& Cycle Time }\end{array}$ & \\
\hline
\end{tabular}




\begin{tabular}{|c|c|c|c|c|c|}
\hline 4. & $\begin{array}{c}\text { Insertion of } \\
\text { Components } \\
\text { Manually on } \\
\text { Bottom Side }\end{array}$ & Medium & Low & Nil & $\begin{array}{c}\text { soldering } \\
\text { With the } \\
\text { help ofa } \\
\text { bottom side } \\
\text { Jig,the } \\
\text { component } \\
\text { can be held } \\
\text { \& Manual } \\
\text { soldering to } \\
\text { be replaced } \\
\text { by wave } \\
\text { soldering }\end{array}$ \\
\hline 5. & $\begin{array}{c}\text { Soldering of } \\
\text { Components }\end{array}$ & High & Yes & $\begin{array}{c}\text { Consumption } \\
\text { of } \\
\text { Consumables } \\
\text { \& Cycle Time }\end{array}$ & \\
\hline
\end{tabular}

\section{A. Challenges for designing of Jigs:}

1. PCBis having an SMD component on both sides \& hence wave soldering can't be done directly and can't be done in one go [4].

2. For Avoiding the manual soldering design of jig is to be done in such a way that components can be held without the need for spot soldering which is required for holding components and subsequently PCB can be wave soldered.Also,the design should be in such a way that height of SMD Components to be coveredin a jig by having a cavity.

3. Design of Jig should be done in such a way maximum length of wave soldering bath [5] can be utilized.

4. It was observed that only $40 \%$ to $50 \%$ area of wave soldering bath was utilized in the wave soldering process.

5. Two types of Jigsmust be designed for wave soldering of the top and bottom side of PCB.

\section{B. Advantage of Jig:}

1.Manual Soldering process to be replaced with wave soldering process which will increase throughput, quality of soldering, brings uniformity [6].

2.Consumption of Consumables like Soldering bits, soldering iron, Spot Mask will be reduced.

3. Max. Length of Wave SolderingBath [7] will be utilized which will increase throughput and save electricity.

4. Manpower requirement will be reduced by the use of Jig.

5. Delivery Targets can be achieved by utilization of Jig.

C. Ensure to meet critical factors is shown in Table 4.

Table 4: Critical factor analysis

\begin{tabular}{|c|c|}
\hline Critical Factor & Suggested Process \\
\hline 1. Manual Operation of Process. & 1. To be Automized/semi automized. \\
\hline $\begin{array}{l}\text { 2. Use Consumables soldering bits, Flux, } \\
\text { Soldering Wire, Spot Mask. }\end{array}$ & $\begin{array}{l}\text { 2. Drastic reduction in consumption of } \\
\text { consumables like soldering bits \& almost } \\
\text { elimination of use soldering wire, Spot }\end{array}$ \\
\hline
\end{tabular}




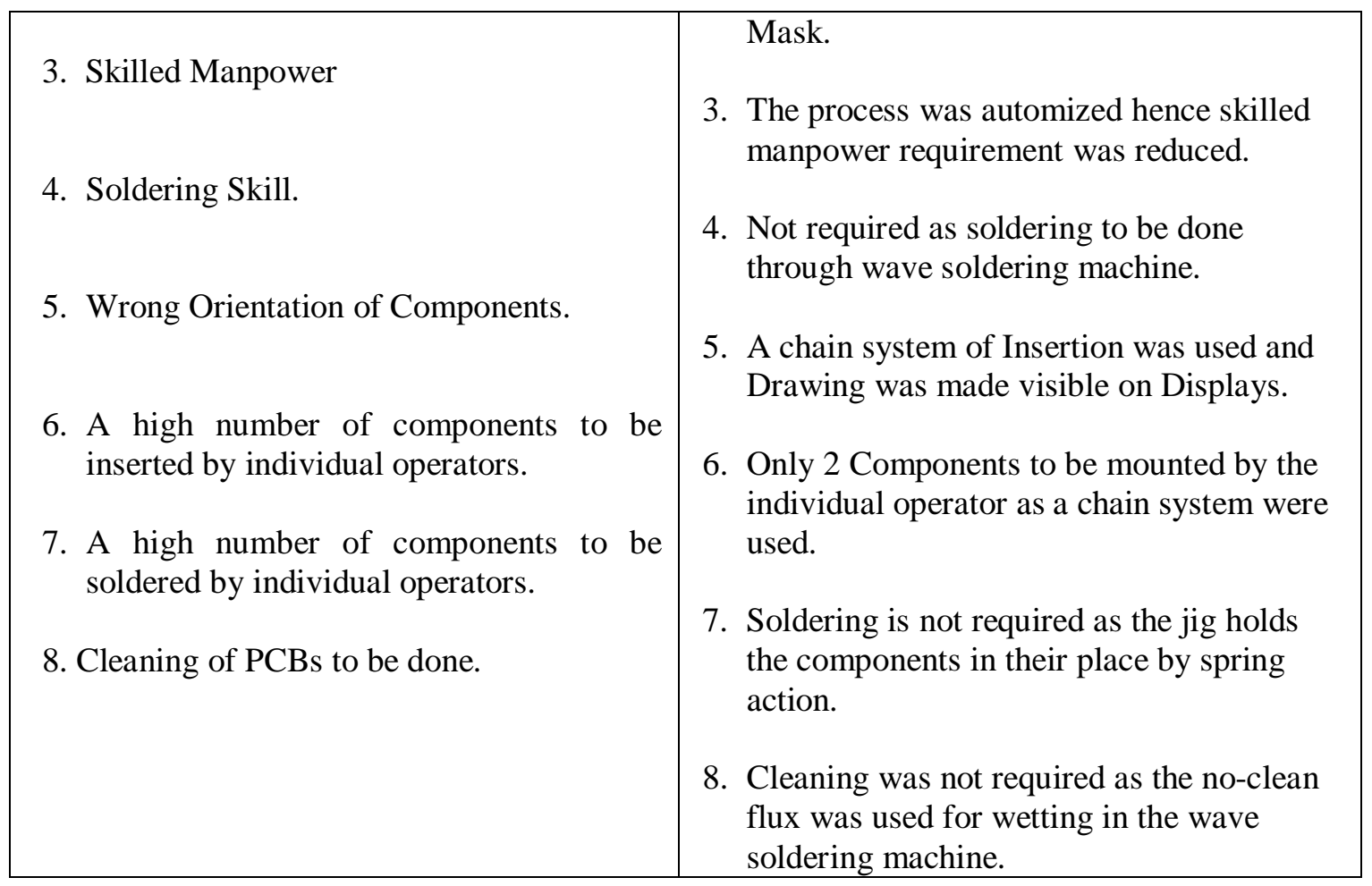

\section{Decision of Jig:}

After weighing all pros and cons, it is decided that manual components insertion along with wave soldering process could be one combination for production [8]. Since either side of the components has surface-mounted devices, hence it is decided to have one type of fixture for each side [9].

\section{E. Pallets design:}

Pallets are designed such that they can cover the conveyor of the Wave soldering machine to get maximum throughput. A pallet is shown in Fig 2.

\section{Fig2:Pallet of PCB}

To hold the component at the right place such that the component does not lift during wave soldering, operation all supports are made with spring load. Spring-loaded pallet photograph is shown in Fig 3. The photograph of the wave soldering pallet with PCB is shown in Fig 4. 


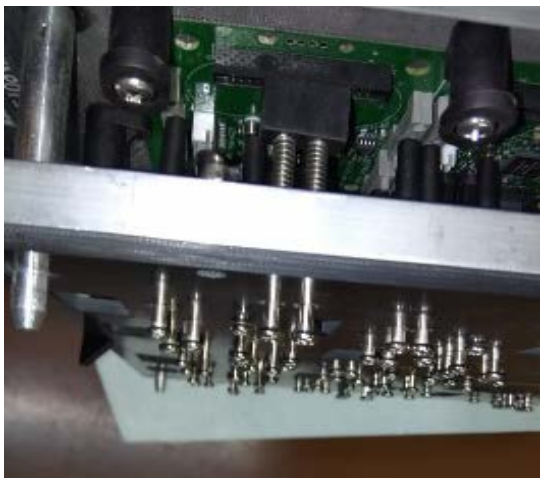

Fig3: Spring loaded pallet

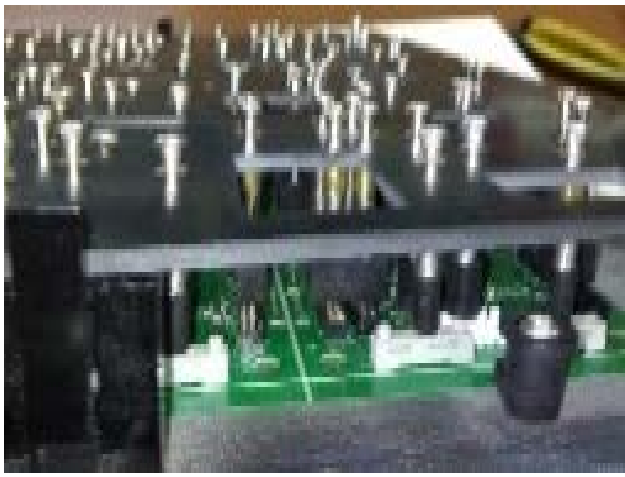

Fig 4: PCB with pallet

F. Time require for soldering of Lead

D. Component:

\section{Length of Conveyor $=4$ Meters}

2. Speed of Conveyor= 1.2 Meters per Minute

3. Size of Wave Pallet $=445 \times 450 \mathrm{MM}$

4. Conveyor Accommodation Capacity of Pallet $=8$ Nos

5. One Pallet accommodates $=2$ Panel=12 PCBs

6. 8 Pallet wave soldering time $=4 / 1.2=3.3$ Minutes

7. 8 Pallet i.e., 96 PCBs Soldering time $=3.3$ Minutes

8. 1 PCB Soldering time for one side $=3.3 / 96=0.034$ Minutes

9. 1 PCB Soldering time for both side $=0.034 \times 2=0.068$ minutes

10. Saving of Soldering Time $=13-0.068=12.93$ Minutes/PCB

11. Insertion time saving with Chain system $=6$ Minutes

12. Total Time saving $=12.93+6=18.93$ Minutes per PCB

\section{G. New process:}

New process steps are shown in Table 5. 
Table 5: New Process with timing

\begin{tabular}{|l|l|c|}
\hline Sr. No. & \multicolumn{1}{|c|}{ Process step } & \multicolumn{1}{|c|}{$\begin{array}{c}\text { Operation timing } \\
\text { in minutes }\end{array}$} \\
\hline 1, & $\begin{array}{l}\text { Insertion of Leaded Components on the } \\
\text { First side }\end{array}$ & 2 \\
\hline 2. & $\begin{array}{l}\text { Soldering of Leaded Component on First } \\
\text { Side }\end{array}$ & 0.034 \\
\hline 3 & $\begin{array}{l}\text { Insertion of Leaded Components on the } \\
\text { Second side }\end{array}$ \\
\hline 4 & $\begin{array}{l}\text { Soldering of Leaded Component on the } \\
\text { second Side }\end{array}$ & 3 \\
\hline 5 & Offering through ESD container & 0.034 \\
\hline & Total Time & 0.1 \\
\hline
\end{tabular}

\section{Result:}

A. Comparison of improved process result with conventional process result is shown in Table 6.

Table 6: Comparison of Process

\begin{tabular}{|c|c|c|}
\hline Sr. No. & Process & Assembly Time \\
\hline 1 & $\begin{array}{c}\text { Leaded assembly cycle time of } \\
\text { logic card (Before } \\
\text { improvement): }\end{array}$ & 24.5 Minutes \\
\hline 2 & $\begin{array}{c}\text { Leaded assembly cycle time of } \\
\text { logic card (After Improvement): }\end{array}$ & 5.17 Minutes \\
\hline
\end{tabular}

B. Assembly process cycle time comparison is shown in Fig 5.

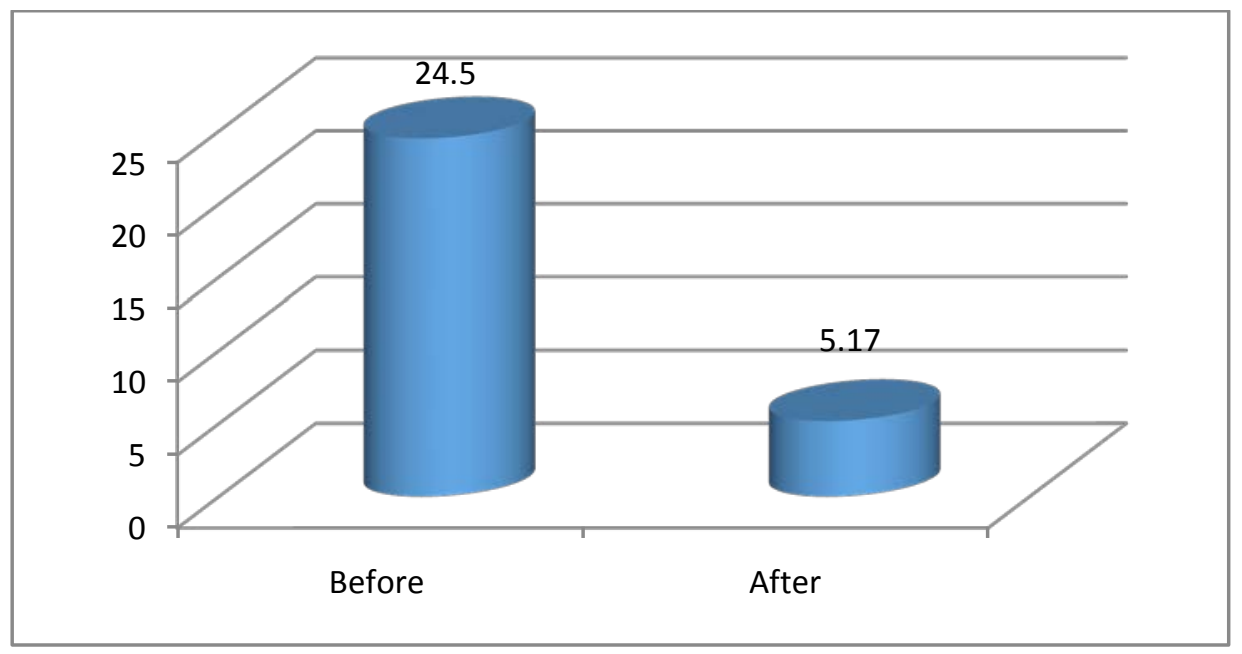

Fig5: Assembly time comparison 


\section{Comparison of timing:}

A comparison ofPCB timings before and after improvement is shown in Table 7.

Table 7: Comparison of Timings

\begin{tabular}{|c|c|c|}
\hline Sr. No. & $\begin{array}{c}\text { Leaded assembly cycle } \\
\text { time of logic card of 12 } \\
\text { PCB before improvement }\end{array}$ & $\begin{array}{c}\text { Leaded assembly cycle } \\
\text { time of logic card of 12 } \\
\text { PCB(one Panel) after } \\
\text { improvement }\end{array}$ \\
\hline 1. & 24.6 mins & 5.16 mins \\
\hline 2. & 24.5 mins & 5.16 mins \\
\hline 3. & 24.5 mins & 5.16 mins \\
\hline 4. & 24.5 mins & 5.16 mins \\
\hline 5. & 24.6 mins & 5.16 mins \\
\hline 6. & 24.5 mins & 5.16 mins \\
\hline 7. & 24.5 mins & 5.16 mins \\
\hline 8. & 24.4 mins & 5.16 mins \\
\hline 9. & 24.7 mins & 5.16 mins \\
\hline 10. & 24.5 mins & 5.16 mins \\
\hline 11. & 24.3 mins & 5.16 mins \\
\hline 12. & 24.5 mins & 5.16 mins \\
\hline
\end{tabular}

D. ' $t$ ' test result:

' $\mathrm{t}$ ' test is conducted to find out whether the process timing of after and before improvement isstatistically significant or not shown in Fig 6.

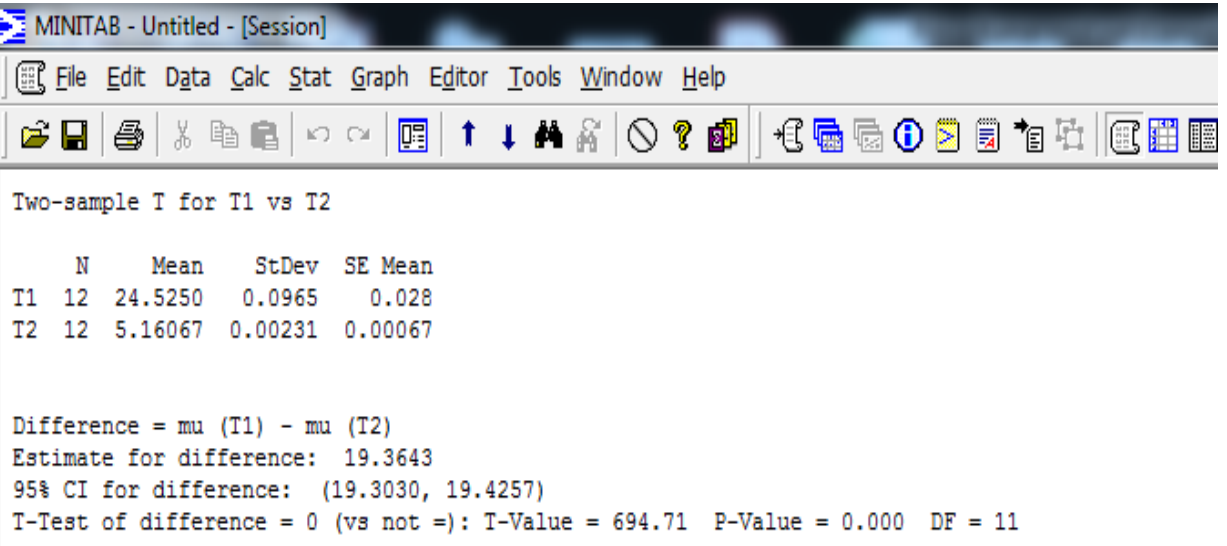




\section{Fig6:Result of ' $t$ 'test}

E. New process flow diagram:

A new process flow diagram is shown in Fig 7.

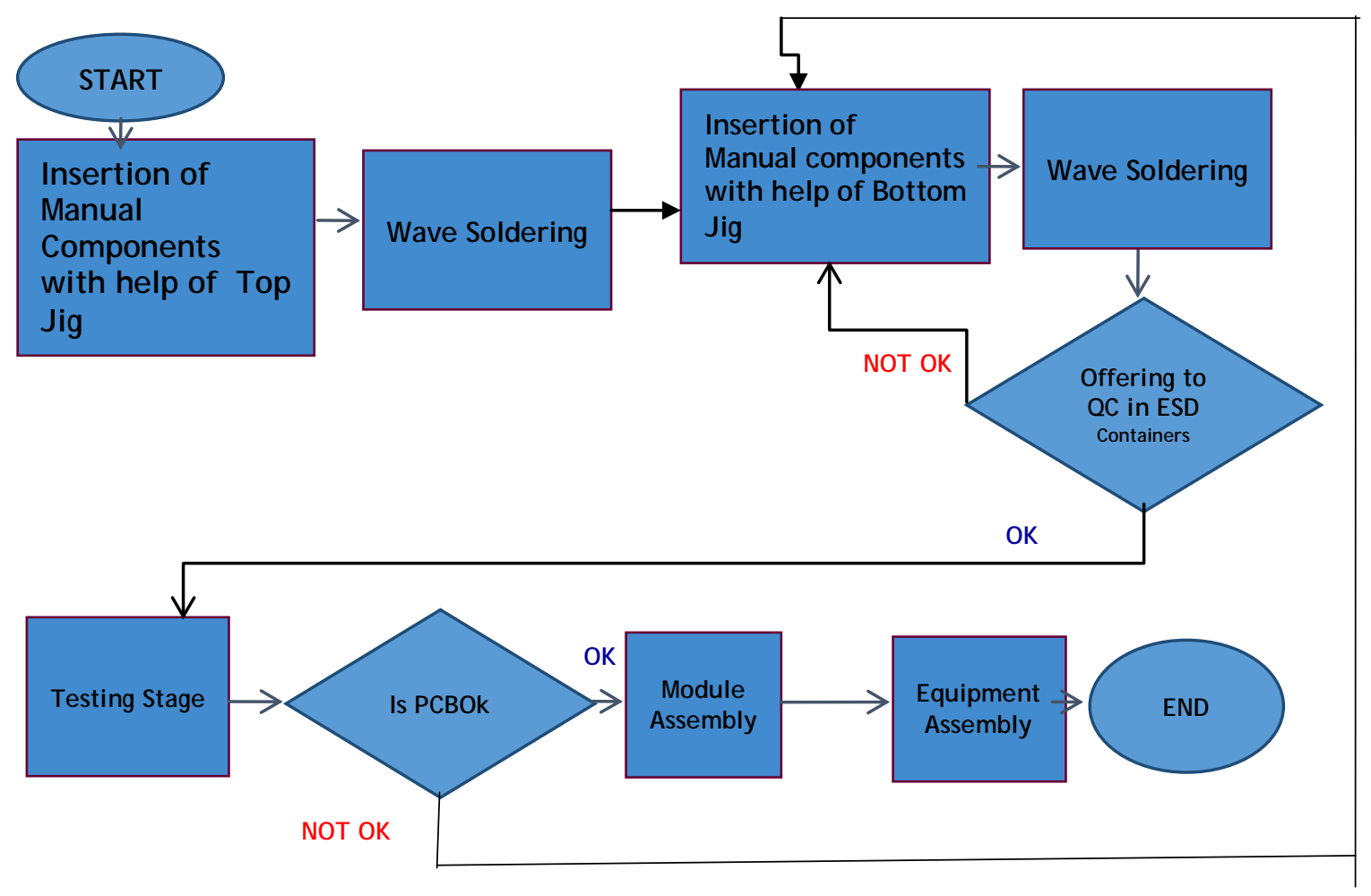

Fig 7: New Process Flow Diagram

\section{Conclusion:}

A. Tangible benefits are obtained as shown in Table 8 .

Table 8: Tangible Benefits

\begin{tabular}{|c|c|c|}
\hline Sr. No & Saving of Consumables Description & Benefits \\
\hline 1 & Soldering Tip SFP-CH10 & No Fumes \\
\hline 2 & Soldering Tip SFP-CH15 & No Fumes \\
\hline 3 & ESD Safe-ESS Bag 100x150 & $\begin{array}{c}\text { Avoided Wastages of ESD } \\
\text { Bags }\end{array}$ \\
\hline 4 & Soldering Wire, No Clean Solder & $\begin{array}{c}\text { Avoided Wastages of Wire } \\
\text { Flux }\end{array}$ \\
\hline 5 & Offering to QC in ESD Containers & $\begin{array}{c}\text { Avoided Breakage of } \\
\text { Components \& time saving }\end{array}$ \\
\hline
\end{tabular}

\section{B. Intangible benefits:}

The following are the intangible benefits

1. Customer SatisfactionImproved. 
2. Process improved.

3. Less Fatigue.

4. Greater employee satisfaction.

5. Better working environment.

\section{References:}

1. Wojciechowski. D, M. Chan, F. Martone, "Lead-free plastic area array BGAs and polymer stud grid arraysTM package reliability", Microelectronics Reliability, vol. 41, no. 11(2001), pp. 1829-1839.

2. C. Y. Ni, D. S. Liu, C. Y. Chen, "Procedure for design optimization of a T-cap flip chip package", Microelectronics Reliability, vol. 42, no. 12,(2002) pp. 1903-191.

3. M. Abtew, G. Selvaduray, "Lead-free solders in microelectronics", Mater. Sci. and Eng. R, vol. 27, no. 5-6,(2000) pp. 95-141.

4. M. Li, H. Xu, J. KIM, H. KIM, "Failure Modes of LeadFree Solder Bumps Formed by Induction Spontaneous Heating Reflow", J. Mater. Sci. Technol., vol. 23, no. 1,(2007), pp. 61-66.

5. M. Arra, D. Shangguan, S. Yi, R. Thalhammer, H Fockenberger, "Development of Lead-Free Wave Soldering Process", IEEE Transactions on Electronics Packaging Manufacturing, vol. 25, no. 4,(2002),October.

6. V. Sunappan, P. Collier, "Lead-free Wave Soldering Development for PCB Assembly", IEEE Electronic Components and Technology Conference, 2003.

7. K. Suganuma, Lead-Free Soldering in Electronics, Marcel Dekker Inc., (2004), pp. 271-285,.

8. T. Gyemant, "Lead-free Wave Soldering: A Cost-effective Alternative", Surface Mount Technology (SMT), December 2003.

9. T. Takemoto, Y. Joo, S. Mawatari, R. Kato, "Reduction of dross formation during wave soldering using lead-free solders", Proc.2nd Int.Symp. Environmentally Conscious Design Inverse Manufact.,(2001), pp. 1131-1136, Dec.. 